\title{
Design and Implementation of Online Teaching Platform
}

\author{
Xin YANG \\ Department of Computer, Wuhan polytechnic, Wuhan 430074, China \\ 627813470@qq.com
}

Keywords: online examination system; online video course playing system; online teaching resources download system.

\begin{abstract}
This paper introduces the design and implementation of computer network professional online teaching platform. This online teaching platform USES LAMP(Linux + Apache + MySQL + PHP) as the development and operating environment. It mainly includes online examination system, teaching resources download system and online video course playing system. They are a closely related organism.
\end{abstract}

\section{Introduction}

The online teaching platform adopts PHP+APACHE+MYSQL development and operation platform. The development language USES PHP, the server USES Apache, the server operating system USES Linux, the database USES MySQL. PHP is the most popular Web language running on the server. Apache is the most stable and popular web server. MySQL is one of the three most popular databases today. Adopt the popular B/S architecture. The main functions of online examination system, online video playback system and teaching resources download system are mainly realized. It is divided into front and back part: Front desk for student users online learning, Background management for admin user background.

The online examination system is responsible for students' online exams; The online teaching resources download system is responsible for downloading resources online; The online video course playing system is responsible for online play learning video.

\section{Design and Implementation of Online Examination System}

The online examination system is the most important component of the online teaching platform, which is responsible for the students' online examination, and can be used as a software application and various examinations.

\section{Function Design of Online Examination System}

Function design of online examination system: to achieve online examination of multiple classes, it supports choice questions, multiple-choice questions and judgment questions.

Fault tolerance: if there's an error in the exam, the examination machine can be replaced, the examination time and answer information still exist in the database.

Check the function of test paper: the examinee has an objection to the examination results, the examination paper can be checked through the online examination platform.

Function of test paper analysis: at the end of the test, the total score, average score, the number of failed persons, the highest score and the lowest grade examination information can be counted.

\section{Function Implementation of Online Examination System}

Implementation of fault tolerant function: if the exam computer is out of order, changing the computer test can restore the examination information. The implementation of this function is as follows:

The answer information is stored in the server database in the exam process. When the examinee enters the examination server, the program reads the examinee's information from the examination server, including the class, name, student id, question information and answer information. In order to 
save the answer information and withdraw the question information, only keep the title id and the answer id. In the examination process, the examinee's every answer is saved to the server, even in the exam, the exam computer is out of order, after changing the test computer, the examination program can read the detailed information of the examinee including the answer information from the server. Real time the examinee answer information saved to the server. It requires the network effect is very good. If the network effect is not good, you can consider offline examination online submission. The examinees do not need network support during the exam, but they need network support when submitting. In today's network environment is generally better, the machine hardware configuration is higher, the real-time preservation of examinee answer information is more popular.

Realization of examination paper verification function: After the examinee submits the examination paper, the procedure must not only count examinee's score, but also saves the question information, the score situation saves in the server database. When the examinee asks for checking his own examination paper, the program will read the examinee's answer and score, and show it on the examination paper.

Realization of test paper analysis function: export all examinee's information to Excel spreadsheet. In the process of exporting examinee's scores, the program uses structured query statements to calculate the highest, lowest and average points, calculate the number of failed persons, and calculate the number of people in each fraction interval. In addition, the examinee score information is stored in the two-dimensional array, and then through the sorting function of the array to get the examinee ranking.

\section{Design and Implementation of Online Video Course Playing System}

The online video course playing system USES a third-party excellent playback plugin to support popular mp4 video format files for online courses.

\section{Function Design of Online Video Course Playing System}

The fluency of the course video plays back: The fluency of the course video is an important feature of the class platform.

The strong interactivity of the course video playing system: Any teacher in the course group can upload video and preview video through the backstage management system, which is fast and interactive.

Flexible handling of video forward, backward, fast forward, and download.

\section{Function Implementation of Online Video Course Playing System}

Implementation of fluency plays back of online video course playing system: Using 720P resolution class video, rather than using 1080P resolution class video. The former volume is less than half of the latter, which contributes to the fluency of video playback, and the 720 resolution can also ensure the clarity of the class video. Placing the server in the school rather than the outside cloud platform helps to save network bandwidth and improve the speed of video courses.

The online video course playing system using third party controls,

The implementation of strong interactivity of the course video playing system: The online teaching platform provides a special background program for administrators of the teachers to upload, download and preview class videos.

The online video course playing system using third party player plug-in. This third party player plug-in is powerful, video plays well, can realize the original size play, full screen play, it also has features such as pauses, regressions, repeated playback, and downloads. All video is recorded by teachers themselves and there is no copyright issue. Students can download these courses video to their own computer and then play the study, video is more fluid on students' local computers. 


\section{Design and Implementation of Teaching Resources Download System}

The teaching resources download system includes the foreground and background, the backstage is used for teachers to upload teaching resources, and the front desk is used to download resources for students.

\section{Function Design of Teaching Resources Download System}

Download the course resources: the teaching resources download system can upload and download various teaching resources. These teaching resources include two broad categories: suitable for teachers' teaching resources, this kind of resource must be very rich, has certain prospective and advanced nature; the teaching resources which are suitable for students to learn must be matched with the teaching content.

\section{Function Implementation of Teaching Resources Download System}

Create a data table to hold the details of the resource. The teaching resource information is stored in this database table according to different categories. The title of these resources is displayed in the form of a list for users to download on the teaching resources download system. Any resource exists in the form of a file, and users can download these resources by clicking on the hyperlink.

\section{Conclusion}

The online teaching platform includes the online examination system, the teaching resource download system and the online video class system. They are a closely related organism. They are organically combined in the course clues. In addition, the online examination system is very powerful and can be used separately in the midterm and final exams.

The online teaching platform used for years in the teaching process, the effect is very good. We will be preparing to apply for the project as a provincial project.

\section{References}

[1] PHP \& MySQL Website development introduction and improvement [M]. WANG Weiping HE Chunlei. Beijin.Tsinghua university press. 2014.7.

[2] PHP programming network lecture hall [M]. ZHU Junchen JIN Yilin. Tsinghua university press. 2011.1.

[3] PHP + MySQL development practices [M]. Network technology development alliance. Beijin.Tsinghua university press. 2013.9.

[4] PHP network programming [M]. MA Shuqing,GUO Tianjiao.Beijing: Electronic industry press.2014.

[5] 21 days learning PHP[M]( The second edition).CHEN Hao.Beijing: Electronic industry press.2011.7.

[6] PHP+MySQL website development application from beginning to mastery.LIU Jianyun.Beijing: China railway publishing house.2015.9.

[7] PHP development of actual combat[M].PAN Kaihua. Beijin.Tsinghua university press. 2014.9.

[8] Lester S E, McLeod K L, Tallis H, et al. Science in support of ecosystem-based management for the US West Coast and beyond[J]. Biological Conservation, 2010, 143(3):

[9] Kim G, Shin B S, Lee H G. Understanding dynamics between initial trust and usage intentions of mobile banking[J]. Information Systems Journal, 2009, 19(3): 283-311. 
[10] Kang S C, Snell S A. Intellectual capital architectures and ambidextrous learning: a framework for human resource management[J]. Journal of Management Studies, 2009, 46(1): 65-92.

[11] PHP 24 classroom learning[M]. Pan Kaihua. Beijin.Tsinghua university press. 2011.6.

[12] Information on http://www.phpchina.com/. 